\title{
OIL FROM SEEDS OF VARIOUS GRAPE CULTIVARS GROWN IN SOUTHERN POLAND AND ITS ANTIOXIDANT PROPERTIES
}

\author{
Renata Francik $^{1}$, Miroslaw Krosniak ${ }^{1}$, Maciej Gastol ${ }^{2}$, Elzbieta Kondratowicz-Pietruszka ${ }^{3}$ \\ ${ }^{1}$ Jagiellonian University, Poland; ${ }^{2}$ University of Agriculture in Krakow, Poland; \\ ${ }^{3}$ University of Economics Krakow, Poland \\ renata.francik@uj.edu.pl,mfkrosni@cyf-kr.edu.pl,rogastol@ogr.ur.krakow.pl, \\ kondrate@uek.krakow.pl
}

\begin{abstract}
In Poland seeds from grape are a waste product that is not used as a source of valuable substances for humans. The main aim of this study was to obtain and analyze the oil from the seeds of seven grape cultivars from the Garlicki Lamus vineyard located in Garlica Murowana (near Krakow, Poland, coordinates: 1956'E, $50^{\circ} 08^{\prime} \mathrm{N}$ ). Our work is presenting estimation of the percentage content of oil and fatty acid composition derived from cultivars of grape seed (Leon Millot, Jutrzenka, Bianca, Regent, Seyval Blanc, Marechal Foch, Sibera). In samples the following fatty acids have been determined: C18:2 from $76.69 \%$ (Bianca) to $81.33 \%$ (Marechal Foch), C18:1 from 10.67\% (Marechal Foch) to $14.15 \%$ (Sibera), C16:0 - from 5.05\% (Seyval Blanc) to $7.40 \%$ (Bianca), C18:0 (stearic acid) from $2.10 \%$ (Sibera) to $3.16 \%$ (Seyval Blanc). On the other hand, the lowest concentration was found for $\mathrm{C} 18: 3$, the presence of which in measurable amounts was found in four of the seven analyzed vine varieties (Bianca, Regent, Seyval Blanc, Sibera). Also the percentage of the oil obtained from the seeds of the analyzed samples was measured. The maximal concentration of oil was obtained for Sibera $(12.70 \pm 0.88 \%)$ cultivar and the smallest for Marechal Foch $(6.48 \pm 0.49 \%)$. Seeds obtained from grape pomace can provide excellent raw material for the oil, which can be used in many branches of industry. Extracts from the oil were tested for the content of total polyphenols level from $34.7 \mathrm{mg} \cdot 1^{-1}$ (Marechal Foch) to $85.1 \mathrm{mg} \cdot \mathrm{l}^{-1}$ (Seyval Blanc) and total antioxidant status, which was determined by the FRAP (Ferric Reducing Antioxidant Power) method from $19.72 \mu \mathrm{molFe}{ }^{2+} \cdot 1^{-1}$ (Marechal Foch) to $817.64 \mu \mathrm{molFe} \mathrm{F}^{2+} \cdot 1^{-1}$ (Sibera). In addition, antioxidant capacity was measured, using the method of reduction of DPPH radical reduction. The lowest activity was measured for Regent $(4.65 \%)$ and the highest for Marechal Foch $(11.62 \%)$. There has also been strong antioxidant potential for two of the seven studied grape seed cultivars - Seyval Blanc and Sibera.
\end{abstract}

Keywords: grape seed oil, fatty acids, FRAP, DPPH, total phenolic content.

\section{Introduction}

Grapevine (Vitis) is a type of vines belonging to the vines (Vitaceae) family, which includes about 60 species, with Vitis vinifera having the greatest economic importance. Extensive research of the true vine showed that the seeds obtained from this species have in their composition many valuable chemicals with beneficial effects on the human body. Compounds belonging to lipids, proteins and polyphenols have been identified in the seeds [1-3].

Grape seed oil (GSO) contains about $90 \%$ unsaturated fatty acids. Linoleic acid (LA) C18: 2 n-6 is 58-78 \%, and oleic acid C18: 1 is 3-15\%, depending on the variety. The high concentration of these components is of great importance in the prevention and treatment of atherosclerosis (effectively reduces high cholesterol). Unrefined grape seed oil contains tocopherols and polyphenolic compounds. The oil itself is additionally characterized by a high smoking temperature (about $190-230{ }^{\circ} \mathrm{C}$ ) $[2 ; 3]$. Polyunsaturated fatty acids $\Omega 3$ [4] and $\Omega 6$ (PUFA) have a positive effect on the human body, mainly due to the antiatherosclerotic action [5].

Research carried out by Richard et all [6] suggests that these acids have antioxidant protection, and combining it with anti-inflammatory effects may be one of the key factors used in the prevention of cardiovascular disease.

In the Middle Ages, viticulture was occupied mainly by clergy, because the wine was used in monasteries for religious purposes. In the past, in the Polish lands, especially in the Middle Ages, there were numerous vineyards. However, the changes of the climate since the 16th century, as well as the growing importance of international trade over the centuries, have led to the number of crops gradually decreasing, almost completely disappearing. Virtually until the end of the 1990s, the vines were grown amateurishly, usually in home gardens, where dessert varieties are usually planted. Most of the varieties used in them were obtained by crossing with American vines, which tolerate low temperatures well [7]. Over the last 20 years, a significant increase in the number of vineyards has been observed in Poland [8]. Due to the climatic conditions necessary for the development of vines, 
varieties have been obtained that can grow in our climate zone (large frosts, incomplete insolation, no breeze). One of these varieties is Jutrzenka bred in Poland.

Vines grown in Polish vineyards are used primarily in the production of wine. However, it should be remembered that many waste materials are generated in the production process. An example of such waste is grape seeds. In accordance with the applicable Polish legislation, this type of waste is subject to obligatory utilization [9].

Most often this is done by burning. However, grape seeds could be a source of vegetable oil, which at the moment is not obtained in our country on a larger scale. Such large-scale processing could be a way to dispose of this waste. The amount of oil obtained is strongly influenced by the used grape variety as well as climatic and soil conditions [10]. The oil obtained from this raw material can be used for culinary purposes, as well as in cosmetology and medicine. The aim of this research was to estimate the percentage, fatty acid composition and test the antioxidant parameters of oil obtained from grape seeds.

\section{Materials and methods}

All reagents were bought from Fluka Chemica company, Switzerland, Sigma Aldrich, POCh S.A.

\section{Obtaining oil from grape seeds}

Grape seed oil was obtained using PH2 vertical laboratory hydraulic press (Taco - Poland). In order to separate the seeds from pulp, those were repeatedly irrigated with water. The obtained material was thereafter precisely purged from pulp residue using a magnetic stirrer. This action was repeated fivefold. This method was identical for every of seven grape varieties. The obtained grape seeds were spread over a large area and dried in room temperature for 48 hours. The dried seeds were then subsequently grinded in a mortar and weighted out.

The prepared foodstock from the tested grape varieties was placed in glass, flat-bottomed flasks with a capacity of $250 \mathrm{ml}$. To such prepared research material n-hexane was added in a ratio 1:1, by mass. Successively the flasks were put in a shaker for 2 hours. After this time, supernatant was poured to sealed, glass, round-bottomed flasks with capacity of $100 \mathrm{ml}$. This action was repeated tenfold in order to completely extract fats. The final stage of obtaining grape seed oil was evaporating dissolvent (n-hexane) from combined extracts (separately for each variety). The Laborota 4000 laboratory evaporator from Heidolph company was used. Evaporation was carried out at a pressure of 340360 mbar, at $52{ }^{\circ} \mathrm{C}$. Every oil sample was stored at $-4^{\circ} \mathrm{C}$ until testing stage.

\section{Determination of the fatty acids amount}

Determination of the fatty acids amount was done using the gas chromatograph SRI 9610C with Restek RTX-2330 column (105 $\mathrm{m}$ in length and $0.25 \mathrm{~mm}$ in diameter, with FID detector, according to the PN-EN ISO 5508 standard). For this purpose an esterification reaction of fatty acids to methyl esters was carried out according to the PNEN IS-O 5509 standard. Each determination was done in three repetitions.

\section{Obtaining methanol - acetone extracts}

Methanol - acetone extracts were prepared from oils of seven different vine grape varieties. $2 \mathrm{ml}$ of each oil was taken and transferred to flat-bottomed flasks (with capacity of $25 \mathrm{ml}$ ). Afterwards, $5 \mathrm{ml}$ of methanol was added. The mixture was thereafter shaken for 1.5 hours in a dark room. After this time, extracts were centrifuged at $4500 \mathrm{rpm}$ for 15 minutes. To oil residue $5 \mathrm{ml}$ of acetone was added. Again, the flask content was shaken. After a period of 1.5 hours centrifugation (under the same parameters) was repeated. Both extracts were combined in a 1:1 ratio. Further analysis was carried out for methanol-acetone extract (EMA).

\section{Measurement of the total antioxidant capacity}

The FRAP assay, which is the modification of the Benzie and Streinís method [11], was applied to measure the ability of the extracted grape seed oil to reduce $\mathrm{Fe}^{3+}$ to $\mathrm{Fe}^{2+}$ ions in acidic environment ( $\mathrm{pH}$ 3.6). $\mathrm{Fe}^{2+}$ ions in the presence of 2,4,6-tripyridyl-Striazine (TPTZ) form $\mathrm{Fe}^{2+}$-TPTZ intensive blue 
complexes, with maximum absorbance at $593 \mathrm{~nm}$. The reaction mixture consisted of acetate buffer $0.3 \mathrm{M}$, (pH 3.6); TPTZ $0.01 \mathrm{M}$ and iron (III) chloride $0.02 \mathrm{M}$. After mixing, the samples were incubated at $37^{\circ} \mathrm{C}$ for $30 \mathrm{~min}$. After that time, the absorbance was measured at a wavelength of $\lambda=593 \mathrm{~nm}$. Blank test was performed similarly, but to the reaction mixture $50 \mu 1$ of distilled water were added. The antioxidant activity was expressed in micromoles of ferrous ions per litter produced by the tested extracts. Every measurement was done three times. Then, the average absorbance for each sample was calculated.

\section{DPPH free radical scavenging activity assay}

Antioxidant properties of the investigated group of grape seed oil were measured by DPPH test based on the method reported by Blois [12]. Generally, DPPH in its stable radical form absorbs at $517 \mathrm{~nm}$, but upon reduction by an antioxidant present in a sample its absorption decreases. Solution $(0.6 \mathrm{mM})$ of 2.2-diphenyl-1-picryl-hydrazyl (DPPH) was prepared in methanol. A fixed volume $(25 \mu \mathrm{l})$ of solutions of each extract was added to $1 \mathrm{~mL}$ of DPPH. Solutions were mixed and incubated in dark at room temperature for $30 \mathrm{~min}$. After that time, the absorbance of samples was measured at $517 \mathrm{~nm}\left(A_{s}\right)$ against the blank sample (methanol) $\left(A_{b}\right)$. As a control, absorbance of DPPH solution with $25 \mu \mathrm{l}$ of distilled water was measured $\left(A_{c}\right)$. The capability of the tested compounds to scavenge the DPPH radical (antioxidant activity) was calculated using the following equation:

$$
\mathrm{DDPH}=\frac{A_{c}-A_{s}}{A_{c}-A_{b}} \cdot 100 \%
$$

where $A_{c}-$ absorbance of the control;

$A_{s}$ - absorbance of the extracts oil;

$A_{b}$ - of the blank (methanol).

\section{Determination of total polyphenol content (TPC)}

The total phenolic content (TPC) of the solvent extracts was determined by the method using Folin-Ciocalteu reagent and gallic acid $\left(\mathrm{mg} \cdot \mathrm{l}^{-1}\right)$ as the standard to produce the calibration curve. The determination was done using the Watehose [13] method. Absorbance was measured under wave length of $\lambda=760 \mathrm{~nm}$ with using the spectrophotometer JASCO V-530.

\section{Statistical analysis}

The results in this study were presented as mean values \pm standard deviations (SD). Statistical differences between the cultivars were analysed by the one-way ANOVA test with percentage of oil, FRAP, TPC and DPPH as the dependent variables and cultivar as effects. Differences were regarded as significant at risk levels of $p<0.05$. The Tukey's HSD (honestly significant difference) test was applied to assess significant differences $(p<0.05)$ between the samples. Statistical analyses were performed with STATISTICA PL software, version 12 (StatSoft, Inc.).

\section{Results and discussion}

The amount of waste produced by the food processing industry is increasing year by year. Recycling of materials containing unbiodegradable compounds may contribute to problems related to environmental pollution. Therefore, rational use of by-products from the food industry is important for environmental protection. One of these possibilities is recovery of biologically active ingredients from plants, which then can be used in the food, cosmetics or pharmaceutical industry. Luque-Rodríguez et al. [14] showed that the oil content of grape seeds changes depending on the variety of grapevine, soil as well as climatic conditions. It usually ranges from 10 to $16 \%$ of dry weight of these seeds.

The percentage of the fat content in seeds is shown in Table 1 . The lowest $(6.48 \pm 0.49 \%)$ and the highest $(12.70 \pm 0.88 \%)$ oil content were observed in red "Marechal Foch" cultivar with medium early and in white "Sibera" cultivar with medium late ripening season of fruits, respectively. The differences in the oil amount between these varieties were statistically significant. The oil content noted in white "Seyval Blanc" (11.71 $\pm 1.02 \%)$ and red "Leon Millot" $(11.39 \pm 0.95 \%)$ cultivars was also significantly higher compared to red "Marechal Foch". Based on our results it can be indicated 
that the oil content of seeds depends on the variety of grape vine. Recently the interest in new natural pro-healthy and therapeutic substances has increased [15-17]. The aim of numerous studies is grape because of high content of polyphenols [18; 19]. It seems important to determine the antioxidant parameters not only in fruit or grape marc [20-23], but also in oil made from their seeds. Therefore, in our study such parameters as: FRAP, DPPH and the total content of polyphenols were determined in methanol - acetone extracts from grape seed oil obtained from the tested cultivars.

The values of total antioxidant activity (expressed as FRAP) between individual varieties of grapevine were significantly different and depended on the cultivar (Table 1). The highest values of FRAP were noticed for white "Sibera" $\left(817.64 \pm 22.59 \mu \mathrm{mol} \mathrm{Fe} \mathrm{F}^{2+} \cdot 1^{-1}\right)$ and white "Seyval Blanc" $\left(724.92 \pm 17.12 \mu \mathrm{mol} \mathrm{Fe} \mathrm{Fe}^{2+} \cdot \mathrm{l}^{-1}\right)$, in turn, the lowest for red "Marechal Foch" $(19.72 \pm 4.08)$ as well red "Leon Millot" (36.05 $\left.\pm 7.06 \mu \mathrm{mol} \mathrm{Fe} \mathrm{F}^{2+} \cdot \mathrm{l}^{-1}\right)$. The values of radical scavenging activity (expressed as DPPH) between individual varieties of grapevine were statistical (Table 1). The highest values of DPPH were noticed for cultivars like white "Seyval Blanc" $(10.49 \pm 1.04 \%)$ and red "Marechal Foch" $(11.62 \pm 0.44 \%)$. Red "Regent" had significantly the lowest value $(4.65 \pm 0.57 \%)$ for this parameter compared to other varieties. The total content of polyphenols in the tested extracts between individual varieties of grapevine was also significantly different and depended on the cultivar (Table 1). The highest values of this parameter were observed both for white "Seyval Blanc" $\left(85.10 \pm 0.01 \mathrm{mg} \cdot \mathrm{l}^{-1}\right)$ and white "Sibera" $\left(80.00 \pm 0.01 \mathrm{mg} \cdot \mathrm{l}^{-1}\right)$. The cultivars like red "Regent" $\left(58.90 \pm 0.01 \mathrm{mg} \cdot \mathrm{l}^{-1}\right)$, white "Bianca" (49.20 $\left.\pm 0.01 \mathrm{mg} \cdot \mathrm{l}^{-1}\right)$ and white "Jutrzenka" (48.70 $\left.\pm 0.01 \mathrm{mg} \cdot \mathrm{l}^{-1}\right)$ had shown statistically lower level of this parameter compared to white "Seyval Blanc" and white "Sibera" cultivars. In turn, the lowest total content of polyphenols was determined in red "Marechal Foch" $\left(34.70 \pm 0.01 \mathrm{mg} \cdot \mathrm{l}^{-1}\right)$.

Percentage of oil content and antioxidant parameters in the seeds of grapevine

\begin{tabular}{|c|c|c|c|c|}
\hline Grapevine & $\begin{array}{c}\text { Percentage of } \\
\text { oil, \% }\end{array}$ & $\begin{array}{c}\text { FRAP, } \\
\mathbf{m m o l ~ F e}^{2+} \cdot \mathbf{l}^{-1}\end{array}$ & DPPH, \% & $\begin{array}{c}\text { Total } \\
\text { polyphenols, } \\
\text { mg. }^{-1}\end{array}$ \\
\hline $\begin{array}{c}\text { Leon Millot } \\
\text { Red cultivars }\end{array}$ & $11.39 \pm 0.95^{\mathrm{k}}$ & $36.05 \pm 7.06^{\mathrm{a}}$ & $10.73 \pm 0.17^{\mathrm{ab}}$ & $38.90 \pm 0.01^{\mathrm{a}}$ \\
\hline $\begin{array}{c}\text { Jutrzenka } \\
\text { White cultivars }\end{array}$ & $9.85 \pm 0.75^{\mathrm{j} . \mathrm{k}}$ & $126.80 \pm 6.30^{\mathrm{b}}$ & $8.61 \pm 2.52^{\mathrm{b}}$ & $48.70 \pm 0.01^{\mathrm{b}}$ \\
\hline $\begin{array}{c}\text { Bianca } \\
\text { White cultivars }\end{array}$ & $9.32 \pm 0.82^{\mathrm{j}}$ & $139.87 \pm 8.98^{\mathrm{b}}$ & $10.13 \pm 1.01^{\mathrm{ab}}$ & $49.20 \pm 0.01^{\mathrm{b}}$ \\
\hline $\begin{array}{c}\text { Regent } \\
\text { Red cultivars }\end{array}$ & $7.88 \pm 0.91^{\mathrm{i}}$ & $185.58 \pm 4.93^{\mathrm{c}}$ & $4.65 \pm 0.57^{\mathrm{ab}}$ & $58.90 \pm 0.01^{\mathrm{c}}$ \\
\hline $\begin{array}{c}\text { Seyval Blanc } \\
\text { White cultivars }\end{array}$ & $11.71 \pm 1.02^{\mathrm{k}}$ & $724.92 \pm 17.12^{\mathrm{d}}$ & $11.45 \pm 0.55^{\mathrm{a}}$ & $85.10 \pm 0.01^{\mathrm{a}}$ \\
\hline $\begin{array}{c}\text { Marechal Foch } \\
\text { Red cultivars }\end{array}$ & $6.48 \pm 0.49^{\mathrm{i}}$ & $19.72 \pm 4.08^{\mathrm{a}}$ & $11.62 \pm 0.44^{\mathrm{a}}$ & $34.70 \pm 0.01^{\mathrm{d}}$ \\
\hline $\begin{array}{c}\text { Sibera } \\
\text { White cultivars }\end{array}$ & $12.70 \pm 0.88^{1}$ & $817.64 \pm 22.59^{\mathrm{e}}$ & $10.49 \pm 1.04^{\mathrm{ab}}$ & $80.00 \pm 0.01^{\mathrm{e}}$ \\
\hline
\end{tabular}

The analysis of the fatty acid profile (Table 2) showed that linoleic acid (C18:2) was present at the largest amount in 2 cultivars: white "Bianca" and red "Marechal Foch" from $76.69 \%$ to $81.33 \%$ respectively. In red "Marechal Foch" and white "Sibera" cultivars also oleic acid (C18:1) was identified. The concentration of this fatty acid ranged from $10.67 \%$ in red "Marechal Foch" to $14.15 \%$ white "Sibera". Other fatty acids identified in the tested grape seed oil were palmitic acid (C16:0) from $5.05 \%$ in "Seyval Blanc" to $7.40 \%$ in "Bianca" and stearic acid (C18:0) from $2.10 \%$ "Sibera" to $3.16 \%$ "Seyval Blanc". $\alpha$-linolenic acid (C18:3) was present at the lowest concentration (measurable quantities) in 4 among 7 analyzed varieties of grapevine like "Bianca", "Leon Millot", "Jutrzenka" and "Regent". 
Composition of grapeseed oil fatty acids

\begin{tabular}{|c|c|c|c|c|c|}
\hline \multirow{2}{*}{$\begin{array}{c}\text { Grape } \\
\text { cultivar }\end{array}$} & \multicolumn{5}{|c|}{ Fatty acid } \\
\cline { 2 - 6 } & $\mathbf{C 1 6 : 0}$ & $\mathbf{C 1 8 : 0}$ & $\mathbf{C 1 8 : 1}$ & $\mathbf{C 1 8 : 2}$ & $\mathbf{C 1 8 : 3}$ \\
\hline $\begin{array}{c}\text { Leon } \\
\text { Millot }\end{array}$ & $5.42 \pm 0.33^{\mathrm{a}}$ & $2.38 \pm 0.14^{\mathrm{a}}$ & $11.50 \pm 0.86^{\mathrm{a}}$ & $80.70 \pm 1.15^{\mathrm{c}}$ & - \\
\hline Jutrzenka & $6.84 \pm 0.47^{\mathrm{b}}$ & $2.20 \pm 0.14^{\mathrm{a}}$ & $10.74 \pm 0.43^{\mathrm{a}}$ & $79.22 \pm 1.22^{\mathrm{b}}$ & - \\
\hline Bianca & $7.40 \pm 0.56^{\mathrm{b}}$ & $2.63 \pm 0.20^{\mathrm{a}}$ & $13.05 \pm 0.82^{\mathrm{b}}$ & $76.69 \pm 0.98^{\mathrm{a}}$ & $0.22 \pm 0.06^{\mathrm{a}}$ \\
\hline Regent & $6.74 \pm 0.49^{\mathrm{b}}$ & $3.15 \pm 0.18^{\mathrm{b}}$ & $11.19 \pm 0.92^{\mathrm{a}}$ & $78.69 \pm 0.63^{\mathrm{b}}$ & $0.20 \pm 0.05^{\mathrm{a}}$ \\
\hline $\begin{array}{c}\text { Seyval } \\
\text { Blanc }\end{array}$ & $5.05 \pm 0.44^{\mathrm{a}}$ & $3.16 \pm 0.18^{\mathrm{b}}$ & $11.07 \pm 0.58^{\mathrm{a}}$ & $80.46 \pm 1.08^{\mathrm{c}}$ & $0.27 \pm 0.06^{\mathrm{a}}$ \\
\hline $\begin{array}{c}\text { Marechal } \\
\text { Foch }\end{array}$ & $5.58 \pm 0.32^{\mathrm{a}}$ & $2.41 \pm 0.12^{\mathrm{a}}$ & $10.67 \pm 0.63$ & $81.33 \pm 1.38^{\mathrm{c}}$ & - \\
\hline Sibera & $6.54 \pm 0.41^{\mathrm{b}}$ & $2.10 \pm 0.11^{\mathrm{a}}$ & $14.15 \pm 0.74^{\mathrm{b}}$ & $76.89 \pm 0.73^{\mathrm{a}}$ & $0.33 \pm 0.06^{\mathrm{b}}$ \\
\hline
\end{tabular}

Grape seeds can be considered as a source of edible vegetable oil. Sabir et al. [24] and Ghoreishi et al. [25] confirm high content of both monounsaturated and polyunsaturated fatty acids in grape seed oil. High amount of linoleic acid (average $\pm 79,14 \%$ ) demonstrates stability of grape seed oil and possibility of using it in industry. The ratio of linoleic acid (C18:2) to oleic acid (C18:1 cis-9) is different from the presented by Sabira et al. [24] and Ghoreishi et al. [25]. However, these differences can be caused among others by more stringent climatic conditions for crops from Poland. Our results showed that grape seed oil is not a rich source of omega- 3 fatty acids.

\section{Conclusions}

1. Grape seeds obtained from marc during wine production in Poland are sources for oil, which can be used in many branches of industries.

2. Our results regarding composition of fatty acids and percentage of the fat content in grape seeds are consistent with the results reported by other authors.

3. The seeds from white Sibera cultivar showed the highest percentage of oil.

4. The seeds from white Sibera cultivar have the largest C18:1 and C18:3 fatty acid content.

5. The grape seeds of two cultivars: white "Seyval Blanc" and white "Sibera" are characterized by higher antioxidant properties.

\section{Acknowledgements}

The authors declare no conflict of interest. The authors would like to thank MSc Agnieszka Satora and MSc. Jadwiga Kryczyk-Kozioł for help.

\section{References}

[1] Maier T, Schieber A, Kammerer DR, Carle R: Residues of grape (Vitis vinifera L.) seed oil production as a valuable source of phenolic antioxidants. Food Chemistry, vol. 112, 2009, pp. 551-559.

[2] Göktürk-Baydar N, Akkurt M: Oil content and oil quality properties of some grape seeds. Turk J Agric For. vol. 25, 2001, pp.163-168.

[3] Bail S, Stuebiger G, Krist S, Unterweger H, Buchbauer G: Characterisation of various grape seed oils by volatile compounds, triacylglycerol composition, total phenols and antioxidant capacity. Food Chemistry, vol. 108, 2008, pp. 1122-1132.

[4] Richard D, Bausero P, Schneider C, Visioli F: Polyunsaturated fatty acids and cardiovascular disease. Cell Mol Life Sci, vol. 66, 2009, pp. 3277-3288.

[5] Das UN: Long-chain polyunsaturated fatty acids, endothelial lipase and atherosclerosis. Prostaglandins Leukot Essent Fatty Acids vol. 72, 2005, pp. 173-179.

[6] Richard D, Kefi K, Barbe U, Bausero P, Visioli F: Polyunsaturated fatty acids as antioxidants. Pharmacol Res vol. 57, 2008, pp.451-455. 
[7] Aichele, Schwegler, Jakie to drzewo?, Wydawnictwo Państwowe i Leśne, (What kind of tree? State and Forest Publishing) 1998; ISBN: 83-09-01646-8 (In Polish).

[8] Wilk K.: Polski rynek win w świetle zmian w krajowych i wspólnotowych uregulowaniach prawnych.(Polish wine market in the light of changes in national and Community legal regulations. Studies and Works) Studia i Prace WNEiZ 2011; 22 (In Polish).

[9] Dziennik Urzędowy Unii Europejskiej Rozporządzenie Komisji (WE) (Official Journal of the European Union Commission Regulation).NR 606/2009 z dnia 10 lipca 2009 (In Polish).

[10]Tangolar SG, Ozoğul Y, Tangolar S, Torun A: Evaluation of fatty acid profiles and mineral content of grape seed oil of some grape genotypes. Int J Food Sci Nutr. vol 60(1), 2009, pp. $32-$ 39.

[11]Blois, M.S. Antioxidant Determinations by the Use of a Stable Free Radical. Nature, vol. 181, 1958, pp. 1199-1200.

[12]Benzie IF, Strain J: The ferric reducing ability of plasma (FRAP) as a measure of Antioxidant Power: The FRAP Assay. Anal Biochem vol. 239(1), 1996, pp. 70-76.

[13]Waterhouse AL: Determination of Total Phenolics. in Curent Protocols in Food Analytical Chemistry R. E. Wrolstad, Ed., units I, pp. I1.1.1-I1.1.8, John Wiley \& Sons, New York, NY, USA, 2003.

[14]Luque-Rodríguez JM, Luque de Castro MD, Pérez-Juan P: Extraction of fatty acids from grape seed by superheated hexane, Talanta vol. 68, 2005, pp. 126-130.

[15]Francik R., Krośniak M., Sanocka I., Bartoń H., Hebda T. and Francik S., "Aronia melanocarpa Treatment and Antioxidant Status in Selected Tissues in Wistar Rats," BioMed Research International, 2014, doi:10.1155/2014/457085.

[16]Francik R., Krośniak M., Francik S., Stawińska J. Evaluation of the fat tissue oxidative stress parameters in Wistar rats in fructose and high-fat diets with the addition of Cornus mas L. and Aronia juice. Acta Poloniae Pharmaceutica - Drug Research, vol. 74 (4), 2017, pp. 1079-1089.

[17]Francik R., Kryczyk-Kozioł J., Krośniak M., Francik S. Activity of paraoxonase 1 and lipid profile in rats fed cornelian cherry or chokeberry in different types of diet. Acta Poloniae Pharmaceutica - Drug Research, vol. 74(6), 2017, pp. 1683-1679.

[18] Garrido J, Borges F. Wine and grape polyphenols - A chemical perspective Food Research International vol. 54, 2013, pp. 1844-1858.

[19]Xia EQ, Deng GF, Guo YJ., Li HB. Biological Activities of Polyphenols from Grapes Int. J. Mol. Sci. vol. 11, 2010, pp. 622-646; doi:10.3390/ijms11020622].

[20]Pérez-Jiménez, S. Arranz, M. Tabernero, M.E.D. Rubio,J. Serrano, I.Goñi, F.Saura-Calixto. Updated methodology to determine antioxidant capacity in plant foods, oils and beverages: Extraction, measurement and expression of results Food Research International, vol. 41, 2008, pp. 274-285.

[21] Pulido R., Bravo L., Saura-Calixto F. Antioxidant activity of dietary polyphenolics as determined by a modified ferric reducing/antioxidant power assay Journal of Agricultural and Food Chemistry, vol. 48, 2000, pp. 3396-3402.

[22] Rockenbach I.I., Silva G.L., Rodrigues E., Gonzaga L.V., Fett R. Atividade antioxidante de extratos de bagaço de uva das variedades Regente e Pinot Noir (Vitis vinifera). (Antioxidant activity of grape bagasse extracts from Regente and Pinot Noir varieties (Vitis vinifera) .Revista do Instituto Adolfo Lutz (Impr), vol. 66(2), 2007, pp. 158-163 (In Portuguese).

[23]Da Porto C, Porretto E, Decorti DE Comparison of ultrasound-assisted extraction with conventional extraction methods of oil and polyphenols from grape (Vitis vinifera L.) seeds, Ultrasonics Sonochemistry vol. 20, 2013, pp 1076-1080.

[24]Sabir A, Unver A, Kara Z: The fatty acid and tocopherol constituents of the seed oil extracted from 21 grape varieties (Vitis spp.). J Sci Food Agric vol. 92, 2012, pp 1982-1987.

[25] Ghoreishi M, Rahmani F, Baneh HD: Determination of fatty acids in some grape cultivars by gas chromatography mass spectrometry, International Research Journal of Applied and Basic Sciences vol. 4, 2013, pp 1467-1471. 